\title{
ERRATUM
}

\section{Erratum to: Amorolfine 5\% Nail Lacquer Exhibits Potent Antifungal Activity Compared to Three Acid-Based Devices Indicated for the Treatment of Onychomycosis: An In Vitro Nail Penetration Assay}

Mahmoud Ghannoum · Karine Sevin · Marlis Sarkany

To view enhanced content go to www.dermtherapy-open.com

Published online: June 10, 2016

(C) The Author(s) 2016. This article is published with open access at Springerlink.com

Erratum to: Dermatol Ther (Heidelb) (2016) 6:69-75 DOI 10.1007/s13555-016-0093-x

In the original publication, in the Methods section, Scholl Fungal Nail Treatment is incorrectly attributed to Bayer Healthcare AG who is neither the manufacturer nor the market authorization holder. This should state Scholl Fungal Nail Treatment, Reckitt Benckiser Healthcare, UK.

The online version of the original article can be found under doi:10.1007/s13555-016-0093-x.

M. Ghannoum $(\bowtie)$

Center for Medical Mycology, University Hospitals of Cleveland and Case Western Reserve University, Cleveland, $\mathrm{OH}, \mathrm{USA}$

e-mail:mag3@case.edu

K. Sevin

Galderma R \& D SNC, Sophia Antipolis, France

M. Sarkany

Galderma International, Paris, France
Open Access. This article is distributed under the terms of the Creative Commons Attribution-NonCommercial 4.0 International License (http://creativecommons.org/licenses/ by-nc/4.0/), which permits any noncommercial use, distribution, and reproduction in any medium, provided you give appropriate credit to the original author(s) and the source, provide a link to the Creative Commons license, and indicate if changes were made. 